\title{
Short communication: Temporal effect of feeding potassium carbonate sesquihydrate on milk fat in lactating dairy cows fed a fat-depressing diet
}

\author{
Guiling Ma, ${ }^{*}$ J. H. Harrison,$\dagger^{1}$ E. Block,‡ T. C. Jenkins, $\S$ and Lynn VanWieringen† \\ *Department of Animal Sciences. Washington State University, Pullman 99164 \\ †Department of Animal Sciences, Washington State University, Puyallup 98731 \\ ¥Church and Dwight Animal Nutrition, Princeton, NJ 08543 \\ $\S$ Department of Animal and Veterinary Sciences, Clemson University, Clemson, SC 29634
}

\begin{abstract}
A lactation study with 10 multiparous dairy cows in early lactation, with an average of 64 days in milk ( standard deviation $=37$ ), were used to evaluate how quickly milk fat concentration would change when potassium carbonate sesquihydrate was abruptly added to the diet. The experiment had 3 periods. In period 1 (d 0 to 7 ) all cows were fed the same basal (control) diet with $1.8 \%$ soy oil, dry basis; in period 2 (d 8 to 28) 5 cows received the control diet, whereas the other 5 cows received the control diet plus $0.59 \%$ of added $\mathrm{K}$ with $\mathrm{K}$ carbonate sesquihydrate; and in period 3 (d 29 to 42) all 10 cows received the control diet. The control diet was formulated for a dietary cation-anion difference (DCAD), calculated as $\mathrm{Na}+\mathrm{K}-\mathrm{Cl}-\mathrm{S}$, of $37.7 \mathrm{mEq} / 100 \mathrm{~g}$ of dry matter (DM), $1.74 \%$ of DM as $\mathrm{K}$, and $5.7 \%$ long-chain fatty acids (DM\%), which included $1.8 \%$ of DM as soybean oil. Period 1 was used as a covariate. In period $2, \mathrm{~d} 8$ to 28,5 cows remained on the control diet whereas 5 cows were fed with the control diet plus $\mathrm{K}$ carbonate sesquihydrate (DCAD+ diet; DCAD of $54.3 \mathrm{mEq} / 100 \mathrm{~g} \mathrm{DM}$ and $2.33 \%$ of DM as $\mathrm{K})$. After feeding the DCAD+ diet, we noted a difference in milk fat concentration from 3.9 to $4.3 \%$ within $72 \mathrm{~h}$. Over the $21 \mathrm{~d}$ of period 2, the DCAD+ diet resulted in significantly greater milk fat percentage from 4.0 to $4.3 \%$, lactose from 4.74 to $4.82 \%$, and fat efficiency in the form of fat in milk divided by fat in DMI from 1.27 to 1.49 , without affecting dry matter intake (DMI), milk protein concentration, solids-not fat concentration, $3.5 \%$ fat-corrected milk, and protein efficiency in the form of protein in milk divided by protein in DMI. In period 3 (d 29-42), all cows were again fed the control diet, resulting in a tendency
\end{abstract}

Received March 22, 2016.

Accepted September 26, 2016.

${ }^{1}$ Corresponding author: jhharrison@wsu.edu for greater milk fat concentration, significantly greater lactose concentration, and fat efficiency in the form of fat in milk divided by fat in DMI for the cows having received the $\mathrm{DCAD}+$ diet during period 2. In conclusion, the abrupt addition of $\mathrm{K}$ carbonate sesquihydrate resulted in a greater milk fat concentration and tended to maintain the greater concentration after cessation of $\mathrm{K}$ carbonate sesquihydrate feeding.

Key words: potassium, milk fat, milk fat depression

\section{Short Communication}

Sanchez et al. (1994) reported that when DCAD was between 30 and $50 \mathrm{mEq} / 100 \mathrm{~g}$ of dietary DM (DCAD $=\mathrm{Na}+\mathrm{K}-\mathrm{Cl}$ ), 3.5\% FCM and DMI were maximized with mid-lactation dairy cows (80 to 210 DIM). Milk fat concentration was greatest when $\mathrm{Na}$ was $0.6 \% \mathrm{DM}, \mathrm{K}$ was $1.34 \% \mathrm{DM}$, and $\mathrm{Cl}$ was $0.69 \% \mathrm{DM}$; likewise, there was an additive effect of dietary $\mathrm{K}$ and sodium supplementation in improving DMI and milk fat concentration of dairy cows (Sanchez et al., 1994). A more recent report (Harrison et al., 2012) indicated an increase in milk fat (4.38 vs. $4.01 \%$ milk fat) in cows not showing fat depression when fed a DCAD of $53 \mathrm{mEq} / 100 \mathrm{~g}$ of dietary $\mathrm{DM}(\mathrm{DCAD}=\mathrm{Na}+\mathrm{K}-\mathrm{S}-\mathrm{Cl})$ and $2.07 \% \mathrm{~K}$ DM. Harrison et al. (2012) also observed an increase in raw milk yield (39.5 vs. $41.6 \mathrm{~kg} / \mathrm{d}$ ), which was consistent with the optimal effect of DCAD supplementation suggested by Iwaniuk and Erdman (2015). In addition, it was observed that when $\mathrm{K}$ carbonate sesquihydrate was fed, the proportion of trans-10 C18:1 (0.68 vs. $0.40 \%$ of total fatty acids) in milk decreased, and it was suggested that feeding $\mathrm{K}$ carbonate sesquihydrate could affect ruminal biohydogenation pathways (Harrison et al., 2012).

Increased trans-10,cis-12 CLA is suggested to cause milk fat depression in dairy cows (Baumgard et al., 2001). When cows exhibit milk fat depression, the biohydrogenation pathways could be altered and result in more trans-10,cis-12 CLA and trans-10 C18:1, and 
less cis-9,trans-11 CLA and trans-11 C18:1 (Grinari and Bauman, 1999). Jenkins et al. (2014) conducted fermenter studies to evaluate the effect of increased $\mathrm{K}$ supplementation on biohydrogenation and observed that trans-10 C18:1 decreased linearly, whereas trans-11 C18:1, trans-9,trans-11 C18:2, and cis-9,trans-11 C18:2 increased linearly, and the explanation of the effect of $\mathrm{K}$ was due to a change of $\mathrm{pH}$.

Harrison et al. (2012) demonstrated the advantages of additional $\mathrm{K}$ on milk performance of early-lactating dairy cows, however, it was not established how quickly milk fat concentration would change when $\mathrm{K}$ carbonate sesquihydrate was supplemented. The specific objective of the current in vivo study was to determine how quickly the addition of dietary $\mathrm{K}$ would affect milk fat concentration, as well as to demonstrate differences in concentration of milk trans-11 C18:1 in relation to the addition of $\mathrm{K}$ carbonate sesquihydrate based on a milk fat-depressing basal diet with added soy oil.

Our study was approved by the Institutional Animal Care and Use Committee at Washington State University (IACUC protocol \#04321-001). Ten multiparous dairy cows were assigned to the study with an average of $64(\mathrm{SD}=37)$ DIM and the experiment was conducted between December 2012 and January 2013. The cows were blocked by predicted transmitting ability and separated into 5 pairs. The control diet was formulated to contain a DCAD $(\mathrm{Na}+\mathrm{K}-\mathrm{S}-\mathrm{Cl})$ of $37.7 \mathrm{mEq} / 100$ $\mathrm{g}$ of $\mathrm{DM}(1.74 \% \mathrm{~K}$ of $\mathrm{DM}), 5.7 \% \mathrm{DM}$ as long-chain fatty acids, and $1.80 \%$ of diet DM soybean oil. The DCAD + diet consisted of the control plus $0.59 \%$ added $\mathrm{K}$ and $16.6 \mathrm{mEq} / 100 \mathrm{~g}$ of DM increased DCAD by adding K carbonate sesquihydrate (DCAD Plus, Church \& Dwight Inc., Princeton, NJ) and added soybean oil to $1.73 \%$ of diet DM. The soybean oil was added to induce milk fat depression. In wk 1 (period 1), all the cows were fed control diet. In wk 2 to 4 (period 2), half of the cows were abruptly changed to the DCAD + diet. In wk 5 and 6 (period 3), the DCAD + cows were again fed the control diet. Period 1 was used as covariate for periods 2 and 3 .

Cows were housed in a freestall facility bedded with composted manure. Rations were formulated using AMTS Cattle Pro version 3.3.x (2012, AMTS LLC, Groton, NY). The ration ingredients (DM basis) were corn silage $26.2 \%$, alfalfa hay $25 \%$, timothy hay $3.6 \%$, cottonseed $4.8 \%$, corn distillers $6.5 \%$, and grain mix $33.9 \%$ (Table 1). The difference between the DCAD+ and control diet was the inclusion of $\mathrm{K}$ carbonate sesquihydrate in the grain mix, as shown in Table 1. Diet ingredients were mixed in a mixer wagon (Roto Mix 533-16 Hay Pro, Industrial Systems and Fabrication Inc., Spokane, WA). The TMR was transferred into
Table 1. Ingredients in control and DCAD+ TMR

\begin{tabular}{|c|c|c|}
\hline Item, $\%$ of DM & Control & DCAD + \\
\hline Corn silage & 26.2 & 26.2 \\
\hline Alfalfa hay & 25 & 25 \\
\hline Timothy hay & 3.6 & 3.6 \\
\hline Whole cottonseed & 4.8 & 4.8 \\
\hline Corn distillers & 6.5 & 6.5 \\
\hline Barley, ground & 14.9 & 14.4 \\
\hline Corn grain, ground & 8.7 & 8.3 \\
\hline Soybean meal, $44 \mathrm{CP}$ & 5.0 & 4.8 \\
\hline Soybean oil & 1.8 & 1.7 \\
\hline $\mathrm{DCAD}+{ }^{1}$ & 0.00 & 1.20 \\
\hline Megalac $^{1}$ & 0.95 & 0.92 \\
\hline Sodium sesquicarbonate $^{1}$ & 0.94 & 0.90 \\
\hline Calcium phosphate monobasic & 0.41 & 0.39 \\
\hline Calcium carbonate & 0.35 & 0.34 \\
\hline Trace mineral salt with selenium ${ }^{2}$ & 0.29 & 0.28 \\
\hline Magnesium oxide & 0.25 & 0.24 \\
\hline MetaSmart $^{3}$ & 0.13 & 0.12 \\
\hline Brewers yeast $^{4}$ & 0.05 & 0.05 \\
\hline Yeast culture $^{5}$ & 0.05 & 0.05 \\
\hline Diamond V seleno source $2000^{5}$ & 0.01 & 0.01 \\
\hline Bloat guard $^{6}$ & 0.05 & 0.05 \\
\hline Zinpro4 plex $^{7}$ & 0.04 & 0.04 \\
\hline Mineral oil & 0.03 & 0.03 \\
\hline Vitamin $\mathrm{D}_{3} \operatorname{premix}^{8}$ & 0.02 & 0.02 \\
\hline Vitamin A premix ${ }^{9}$ & 0.02 & 0.02 \\
\hline Vitamin premix ${ }^{10}$ & 0.003 & 0.003 \\
\hline
\end{tabular}

${ }^{1}$ Church and Dwight Co. Inc., Princeton, NJ.

${ }^{2}$ Contained $97.5 \% \mathrm{NaCl}, 0.009 \% \mathrm{Se}, 0.006 \% \mathrm{Co}, 0.01 \% \mathrm{I}, 0.035 \% \mathrm{Cu}$, $0.20 \% \mathrm{Fe}, 0.18 \% \mathrm{Mn}, 0.037 \% \mathrm{Mg}$, and $0.35 \% \mathrm{Zn}$.

${ }^{3}$ MetaSmart, Adisseo, Alpharetta, GA.

${ }^{4}$ Integral, Alltech Inc., Nicholasville, KY.

${ }^{5}$ Diamond V Mills Inc., Cedar Rapids, IA.

${ }^{6}$ Phibro Animal Health (Pty) Ltd., Teaneck, NJ.

${ }^{7} 4$-Plex, Zinpro Corp., Eden Prairie, MN.

${ }^{8}$ Contains $8,818,400 \mathrm{IU}$ of vitamin $\mathrm{D}_{3}$ per $\mathrm{kg}$.

${ }^{9}$ Contains $30,000 \mathrm{IU}$ of vitamin A-acetate per g.

${ }^{10}$ Contains 500,044 IU of vitamin E per kg.

a Calan Super Data Ranger (American Calan, Northwood, $\mathrm{NH}$ ) for feed delivery into individual feed bunks. Cows were fed individually using Calan gates once per day between 1000 and $1200 \mathrm{~h}$. Feed was offered as 5 to $10 \%$ excess of the previous day's intake. Samples of TMR and grain mix were obtained $1 \mathrm{~d}$ per week. Subsamples of the TMR were analyzed for DM, CP, starch, ether extract, ADF, NDF, ash, Ca, P, K, Na, $\mathrm{Cl}$, and $\mathrm{S}$ (Table 2) by wet chemistry (Cumberland Valley Analytical Services, Hagerstown, MD).

Cows were milked twice daily (1100 and $2300 \mathrm{~h}$ ), and milk weights were recorded at each milking. Daily morning and evening composite milk samples were collected and sent to Minnesota DHIA (Zumbrota, $\mathrm{MN}$ ) for analysis (fat, protein, casein, lactose, SCC, and MUN). Additional individual morning and evening milk samples were collected on the last 2 consecutive days of period 1 and the first 4 consecutive day of pe- 
Table 2. Nutrient content of control and DCAD + diets from laboratory analysis (mean $\pm \mathrm{SD}$ )

\begin{tabular}{lcc}
\hline $\begin{array}{l}\text { Item, \% of DM } \\
\text { (unless noted) }\end{array}$ & Control & DCAD ${ }^{1}$ \\
\hline $\mathrm{DM}$ & $54.4 \pm 0.9$ & $55.1 \pm 0.3$ \\
$\mathrm{CP}$ & $16.6 \pm 0.7$ & $16.6 \pm 0.9$ \\
Soluble protein, \% CP & $32.6 \pm 2.5$ & $26.8 \pm 1.7$ \\
Starch & $20.9 \pm 1.2$ & $22.1 \pm 0.4$ \\
$\mathrm{ADF}$ & $22.2 \pm 2.2$ & $21.4 \pm 1.1$ \\
$\mathrm{NDF}$ & $32.0 \pm 2.5$ & $31.0 \pm 1.2$ \\
Ash & $8.3 \pm 0.2$ & $9.0 \pm 0.2$ \\
Ether extract & $5.7 \pm 0.7$ & $5.1 \pm 0.4$ \\
$\mathrm{Ca}$ & $0.90 \pm 0.06$ & $0.86 \pm 0.04$ \\
$\mathrm{P}$ & $0.44 \pm 0.02$ & $0.44 \pm 0.02$ \\
$\mathrm{Mg}$ & $0.38 \pm 0.04$ & $0.39 \pm 0.04$ \\
$\mathrm{~K}$ & $1.74 \pm 0.17$ & $2.33 \pm 0.08$ \\
$\mathrm{Na}$ & $0.48 \pm 0.04$ & $0.50 \pm 0.03$ \\
$\mathrm{Cl}$ & $0.41 \pm 0.02$ & $0.41 \pm 0.02$ \\
$\mathrm{~S}$ & $0.26 \pm 0.01$ & $0.25 \pm 0.01$ \\
$\mathrm{DCAD}{ }^{2} \mathrm{mEq} / 100 \mathrm{~g}$ of DM & $37.7 \pm 2.8$ & $54.3 \pm 2.3$ \\
\hline
\end{tabular}

${ }^{1} \mathrm{DCAD}+($ Church and Dwight Co. Inc., Princeton, NJ) diet was only fed during period 2 .

${ }^{2} \mathrm{DCAD}(\mathrm{mEq} / 100 \mathrm{~g}$ of $\mathrm{DM})=\mathrm{Na}+\mathrm{K}-\mathrm{S}-\mathrm{Cl}$.

riod 2, frozen immediately, and later analyzed for milk fatty acids as described by Jenkins (2010).

Data were analyzed as a randomized complete block design with repeated measurements using the MIXED procedure of SAS version 9.2 (SAS Institute Inc., Cary, NC). Data of period 2 and 3 was adjusted with data of period 1 as a covariate factor; each period was separately analyzed. For period 1, the model included the fixed effects of treatment, day, treatment $\times$ day, and the random effect of cow within block. For periods 2 and 3 , the model included the fixed effects of treatment, day, treatment $\times$ day, covariate, and the random effect of cow within block. Day was the repeated variable and cow was the subject. The AR(1) covariance structure was used in the model. The Kenward-Roger option of the MODEL statement was used to adjust the degrees of freedom and standard error. The SLICE option in the LSMEANS statement was used to compare the 2 treatments at a specific day.

The TMR composition is summarized in Table 2. With the exception of $\mathrm{K}$ and DCAD, the nutrient composition was similar between diets. The $\mathrm{K}$ content in the control versus the DCAD+ diet was 1.74 versus $2.33 \% \mathrm{DM}$, and the corresponding DCAD value was 37.7 versus $54.3 \mathrm{mEq} / 100 \mathrm{~g}$ of $\mathrm{DM}$ (with equation $\mathrm{Na}$ $+\mathrm{K}-\mathrm{S}-\mathrm{Cl}$ for control vs. DCAD + diet), respectively.

The summary of DMI, yield of milk and milk components, milk composition, and productive efficiency for period 1 are shown in Table 3, period 2 are in Table 4, and period 3 are in Table 5 . We observed no effect of $\mathrm{K}$ carbonate sesquihydrate addition on DMI $(P>0.05)$, nor an interaction between diet (K carbonate sesquihydrate) and time for DMI $(P>0.05)$ in period 2 .

In period 1, milk fat concentration was 4.2 versus $4.1 \%$ for cows that subsequently were on control versus DCAD + diets, respectively $(P=0.37)$. In period 2 , the $\mathrm{DCAD}+$ diet resulted in 0.23 percentage unit increase in milk fat concentration $(P<0.05)$, which was a $6 \%$ difference. The interaction between treatment and day was not significant $(P=0.33)$ for milk fat concentration in period 2. However, we wanted to know how soon into period 2 the differences in concentration of milk fat occurred. The results of daily evaluation of milk fat concentration percentage is shown in Figure 1, and milk fat yield is shown in Figure 2. Data analysis (Figure 1)

Table 3. Dry matter intake and milk composition in period 1 for cows fed control or DCAD + diets in period 2

\begin{tabular}{|c|c|c|c|c|c|c|}
\hline \multirow[b]{2}{*}{ Item } & \multicolumn{2}{|c|}{ Treatment } & \multirow[b]{2}{*}{ SEM } & \multicolumn{3}{|c|}{$P$-value } \\
\hline & Control & $\mathrm{DCAD}+{ }^{1}$ & & Treatment & Day & Treatment $\times$ day \\
\hline DMI, $\mathrm{kg}$ & 25.8 & 26.9 & 1.0 & 0.43 & 0.77 & 0.19 \\
\hline Milk yield, $\mathrm{kg}$ & 49.1 & 46.7 & 2.0 & 0.40 & 0.00 & 0.21 \\
\hline Fat, $\%$ & 4.2 & 4.1 & 0.1 & 0.37 & $<0.01$ & 0.06 \\
\hline Fat yield, $\mathrm{kg}$ & 2.04 & 1.91 & 0.09 & 0.31 & $<0.01$ & $<0.01$ \\
\hline Protein, $\%$ & 2.7 & 2.9 & 0.1 & 0.11 & 0.09 & 0.97 \\
\hline Protein yield, kg & 1.34 & 1.35 & 0.05 & 0.88 & $<0.01$ & 0.22 \\
\hline Lactose, \% & 4.7 & 4.9 & 0.1 & 0.16 & $<0.01$ & 0.39 \\
\hline SNF, $\%$ & 8.4 & 8.7 & 0.1 & 0.02 & 0.44 & 0.45 \\
\hline $3.5 \%$ FCM, kg & 54.1 & 51.2 & 2.1 & 0.34 & $<0.01$ & $<0.01$ \\
\hline FCM/DMI, kg/kg & 2.1 & 1.9 & 0.1 & 0.31 & $<0.01$ & 0.03 \\
\hline ECM, kg & 52.0 & 49.7 & 1.9 & 0.41 & $<0.01$ & 0.01 \\
\hline $\mathrm{ECM} / \mathrm{DMI}, \mathrm{kg} / \mathrm{kg}$ & 2.0 & 1.9 & 0.1 & 0.35 & $<0.01$ & 0.04 \\
\hline Fat efficiency, ${ }^{2} \mathrm{~kg} / \mathrm{kg}$ & 1.5 & 1.3 & 0.1 & 0.35 & $<0.01$ & $<0.01$ \\
\hline Protein efficiency, ${ }^{3} \mathrm{~kg} / \mathrm{kg}$ & 0.32 & 0.31 & 0.02 & 0.71 & 0.13 & 0.16 \\
\hline
\end{tabular}

${ }^{1} \mathrm{DCAD}+($ Church and Dwight Co. Inc., Princeton, NJ) diet only fed during period 2.

${ }^{2}$ Fat efficiency is calculated with fat in milk divided by fat in DMI.

${ }^{3}$ Protein efficiency is calculated with protein in milk divided by protein in DMI. 
Table 4. Dry matter intake and milk composition in period 2 for cows fed control or DCAD+

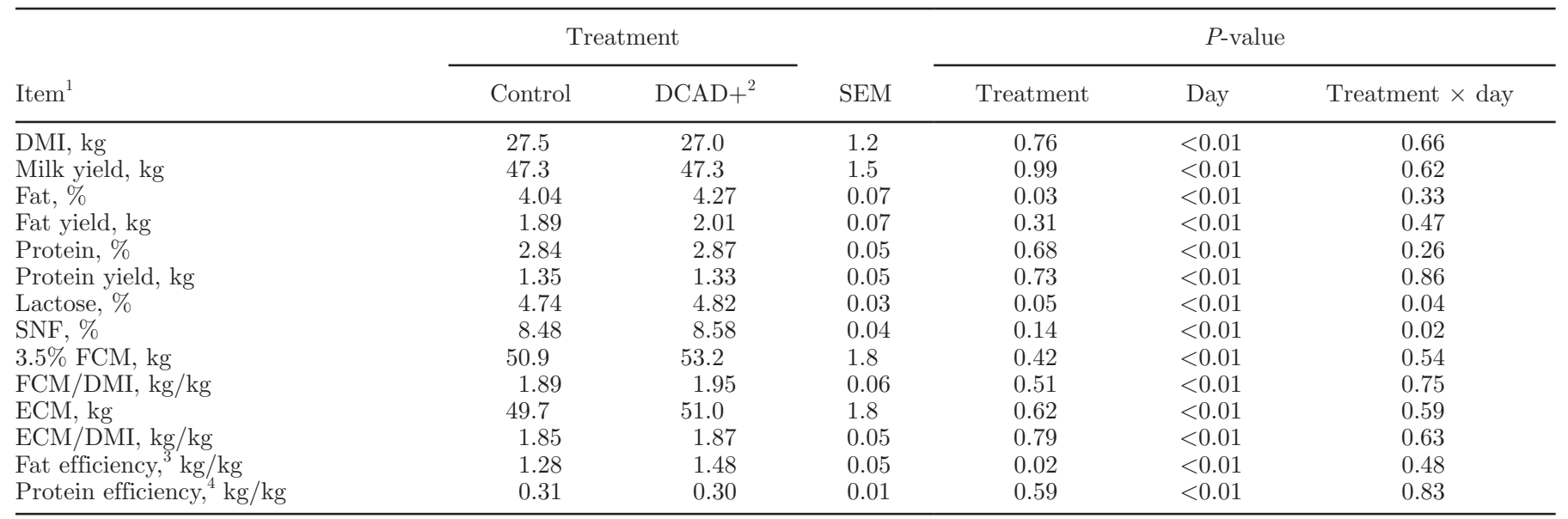

${ }^{1}$ Data were covariate adjusted with data from period 1 .

${ }^{2} \mathrm{DCAD}+$ (Church and Dwight Co. Inc., Princeton, NJ) diet only fed during period 2.

${ }^{3}$ Fat efficiency is calculated with fat in milk divided by fat in DMI.

${ }^{4}$ Protein efficiency is calculated with protein in milk divided by protein in DMI.

indicated a trend for a difference $(P=0.10)$ in milk fat concentration within $2 \mathrm{~d}$ for cows fed $\mathrm{K}$ carbonate sesquihydrate as compared with the control diet. By d 3, the difference in milk fat concentration between diets was significant $(P<0.05)$. Milk fat concentration of $\mathrm{DCAD}+$ tended to be greater than the control group $(P=0.06)$ during the recovery period (period 3 ) with the cessation of $\mathrm{K}$ carbonate sesquihydrate supplementation. This may indicate that the effects of $\mathrm{K}$ carbonate sesquihydrate supplementation on milk fat may influence fat metabolism via the biohydrogena- tion pathways and changes in concentrations of $\mathrm{C} 18: 1$ trans-10 and C18:1 trans- 11 . The timing (within 48 to $72 \mathrm{~h}$ ) of the increase in milk fat concentration due to addition of $\mathrm{K}$ carbonate sesquihydrate between periods 1 and 2 is consistent with reports (Bauman and Griinari, 2001; Rico and Harvatine, 2013) of the timing in the decrease in milk fat concentration induced by feeding of trans-10, cis-12 CLA or low-fiber and high-oil diet. The change in milk fat concentration was detectable within the first $3 \mathrm{~d}$ of period 2 (Figure 1), remained greater during the remainder of period 2 , and continued to be

Table 5. Dry matter intake and milk composition for cows in period 3 fed control or DCAD+ diets in period 2

\begin{tabular}{|c|c|c|c|c|c|c|}
\hline Item $^{1}$ & \multicolumn{2}{|c|}{ Treatment } & SEM & \multicolumn{3}{|c|}{$P$-value } \\
\hline DMI, $\mathrm{kg}$ & 28.7 & 28.2 & 1.4 & 0.78 & $<0.01$ & 0.03 \\
\hline Fat, $\%$ & 3.8 & 4.1 & 0.1 & 0.06 & 0.06 & 0.86 \\
\hline Fat yield, $\mathrm{kg}$ & 1.85 & 1.98 & 0.10 & 0.41 & 0.13 & 0.32 \\
\hline Protein, $\%$ & 2.84 & 2.95 & 0.08 & 0.35 & $<0.01$ & 0.49 \\
\hline $3.5 \%$ FCM, $\mathrm{kg}$ & 49.9 & 53.8 & 2.8 & 0.37 & 0.20 & 0.13 \\
\hline FCM/DMI, $\mathrm{kg} / \mathrm{kg}$ & 1.77 & 1.90 & 0.11 & 0.42 & 0.28 & 0.01 \\
\hline $\mathrm{ECM}, \mathrm{kg}$ & 48.9 & 52.3 & 2.7 & 0.40 & 0.26 & 0.11 \\
\hline $\mathrm{ECM} / \mathrm{DMI}, \mathrm{kg} / \mathrm{kg}$ & 1.72 & 1.85 & 0.10 & 0.37 & 0.31 & $<0.01$ \\
\hline Fat efficiency, ${ }^{3} \mathrm{~kg} / \mathrm{kg}$ & 1.15 & 1.37 & 0.07 & $<0.01$ & 0.36 & 0.05 \\
\hline Protein efficiency, ${ }^{4} \mathrm{~kg} / \mathrm{kg}$ & 0.29 & 0.29 & 0.01 & 0.84 & $<0.01$ & 0.07 \\
\hline
\end{tabular}

${ }^{1}$ Data were covariate adjusted with data from period 1 .

${ }^{2} \mathrm{DCAD}+$ (Church and Dwight Co. Inc., Princeton, NJ) diet only fed during period 2.

${ }^{3}$ Fat efficiency is calculated with fat in milk divided by fat in DMI.

${ }^{4}$ Protein efficiency is calculated with protein in milk divided by protein in DMI. 


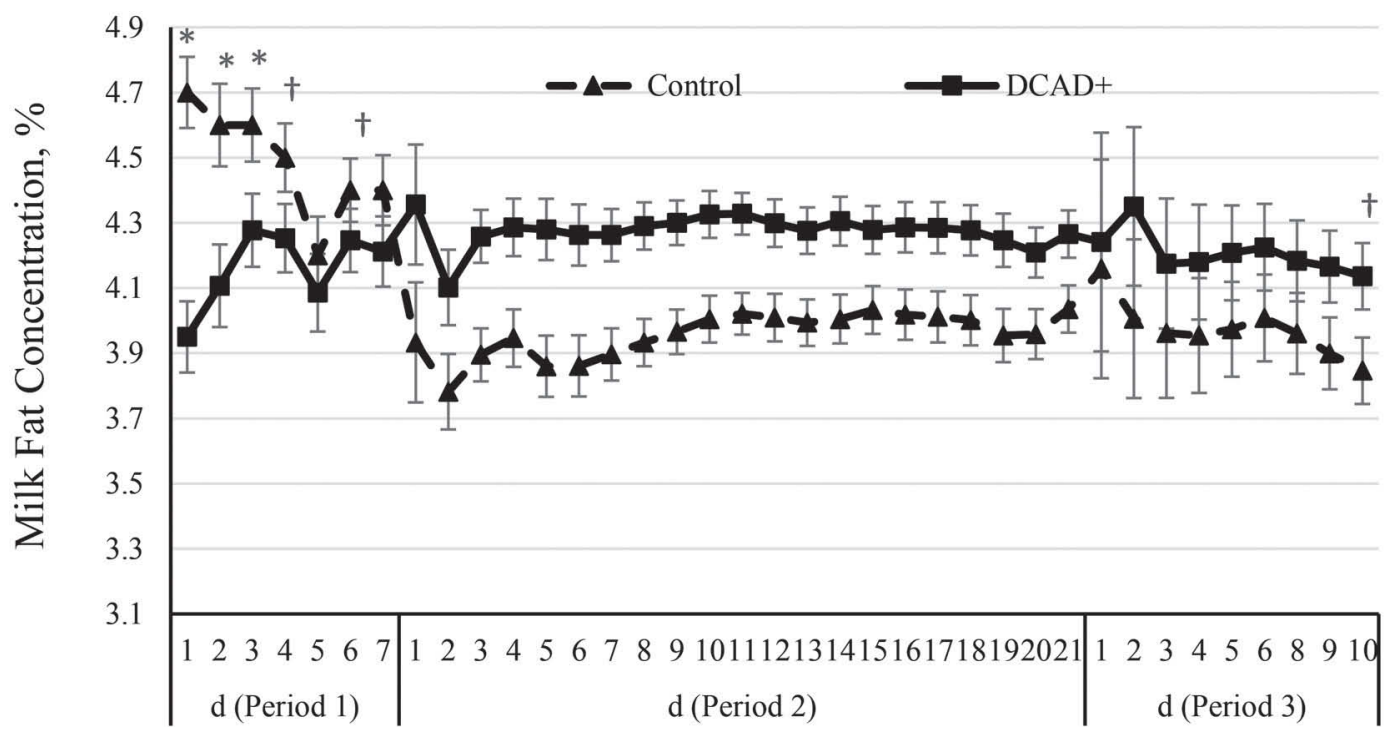

Figure 1. Milk fat concentration for cows when fed control and DCAD + diets during periods 1,2 , and $3 . \dagger P<0.10, * P<0.05$. Periods 2 and 3 were covariate adjusted, $P<0.05$, from d 3 to 21 in period 2. Period 1: treatment (Trt) $P=0.37$, day $P<0.01$, Trt $\times$ day $P=0.06$; period 2: Trt $P=0.03$, day $P<0.01$, Trt $\times$ day $P=0.33$; period 3: Trt $P=0.06$, day $P=0.06$, Trt $\times$ day $P=0.86$. Error bars represent SE.

greater in period 3 after $\mathrm{K}$ carbonate sesquihydrate was no longer fed. We observed no treatment effects on milk protein concentration or yield.

Lactose concentration was not different $(P>0.1)$ between treatment groups for period 1. Potassium carbonate sesquihydrate supplementation resulted in greater lactose concentration by $0.08 \%$ units (Table 4 ; $P=0.05$ ) for period 2 . When $\mathrm{K}$ carbonate sesquihydrate supplementation ceased, lactose content remained greater $(P=0.02)$ for DACD + cows in period 3 .

The DCAD+ group had a greater SNF content in period $1(P=0.02$; Table 3$)$. Potassium carbonate

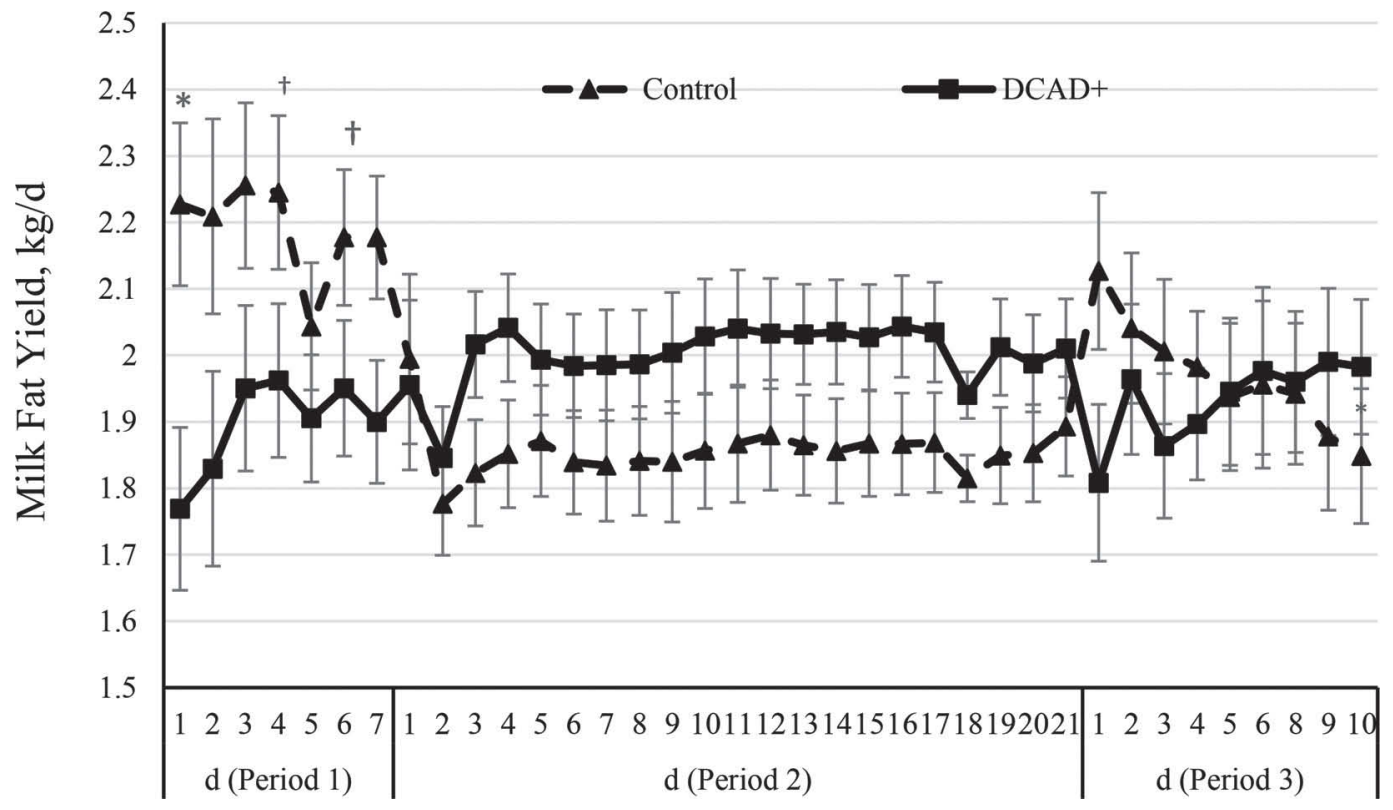

Figure 2. Milk fat yield for cows when fed control and DCAD + diets during periods 1,2 , and $3 . \dagger P<0.10, * P<0.05$. Periods 2 and 3 are covariate adjusted and interpreted as actual means, $1.7 \% \mathrm{~K}$ (control) or $2.3 \% \mathrm{~K}$ (DCAD+, Church and Dwight Co. Inc., Princeton, NJ). Period 1: treatment (Trt) $P=0.31$, day $P<0.01$, Trt $\times$ day $P<0.01$; period 2 : Trt $P=0.31$, day $P<0.01$, Trt $\times$ day $P=0.47$; period 3 : Trt $P=$ 0.41 , day $P=0.13$, Trt $\times$ day $P=0.32$. Error bars represent SE. 
Table 6. Fatty acid (\% of total fatty acids) profile of milk in period 1 for cows fed control or DCAD+ diet in period 2

\begin{tabular}{|c|c|c|c|c|c|c|}
\hline Fatty acid & \multicolumn{2}{|c|}{ Treatment } & SEM & \multicolumn{3}{|c|}{$P$-value } \\
\hline $\mathrm{C} 10: 0$ & 2.1 & 3.6 & 0.18 & $<0.01$ & 0.12 & 0.31 \\
\hline C14:0 & 12.7 & 13.9 & 0.82 & 0.31 & 0.09 & 0.56 \\
\hline $\mathrm{C} 14: 1$ & 0.82 & 0.81 & 0.08 & 0.89 & 0.02 & 0.86 \\
\hline C14:1 trans & 0.08 & 0.07 & 0.02 & 0.75 & 0.01 & 0.58 \\
\hline $\mathrm{C} 16: 1$ & 1.42 & 1.17 & 0.07 & 0.04 & $<0.01$ & 0.14 \\
\hline Ratio C16:1/C16:0 & 0.044 & 0.035 & 0.002 & 0.04 & $<0.01$ & 0.65 \\
\hline $\mathrm{C} 17: 0$ & 0.42 & 0.41 & 0.02 & 0.81 & 0.89 & 0.09 \\
\hline $\mathrm{C} 18: 0$ & 10.2 & 10.3 & 0.6 & 0.97 & $<0.01$ & 0.22 \\
\hline C18:1 trans -8 & 0.26 & 0.23 & 0.08 & 0.84 & 0.02 & 0.15 \\
\hline C18:1 trans -9 & 0.24 & 0.21 & 0.07 & 0.77 & 0.02 & 0.09 \\
\hline C18:2 & 3.6 & 3.7 & 0.2 & 0.70 & 0.63 & 0.59 \\
\hline $\mathrm{C} 18: 2$ cis -9, trans -11 & 0.9 & 0.8 & 0.2 & 0.60 & 0.14 & 0.35 \\
\hline $\mathrm{C} 18: 2$ trans -10, cis- 12 & 0.03 & 0.03 & 0.01 & 0.81 & 0.94 & 0.56 \\
\hline $\mathrm{C} 18: 3$ & 0.54 & 0.59 & 0.04 & 0.38 & 0.68 & 0.84 \\
\hline $\mathrm{C} 20: 1$ trans -11 & 0.89 & 0.78 & 0.17 & 0.68 & 0.18 & 0.45 \\
\hline $\mathrm{C} 22: 1$ & 0.08 & 0.07 & 0.02 & 0.8 & 0.03 & 0.43 \\
\hline $\mathrm{C} 24: 0$ & 1.3 & 1.1 & 0.5 & 0.85 & 0.02 & 0.85 \\
\hline De novo & 20.4 & 23.1 & 1.4 & 0.21 & 0.43 & 0.21 \\
\hline Mixed & 33.6 & 34.0 & 0.9 & 0.78 & 0.6 & 0.03 \\
\hline Preformed & 41.4 & 38.1 & 1.8 & 0.24 & 0.24 & 0.67 \\
\hline
\end{tabular}

${ }^{1} \mathrm{DCAD}+($ Church and Dwight Co. Inc., Princeton, NJ) diet only fed during period 2.

sesquihydrate supplementation had no influence on SNF $(P>0.1)$ in period 2 , whereas we noted a time and treatment interaction $(P<0.05)$. The treatment influence was only significant on d 8 and $21(P<0.05)$ in period 2 . When $\mathrm{K}$ carbonate sesquihydrate supplementation ceased, SNF was not different $(P=0.14)$ in period 3 . The $3.5 \%$ FCM and ECM were not different in periods 1,2 , and 3 .

The fat efficiency in the form of fat in milk divided by fat in DMI was not different $(P=0.35)$ in period 1 ; however, fat efficiency was 0.20 units greater $(P=$ 0.02 ) in period 2 and 0.22 units greater in period 3 for cows fed the DCAD+ diet (in period 2) than cows fed the control diet. The protein efficiency in the form of protein in milk divided by protein in DMI was not different $(P>0.1)$ in periods 1,2 , and 3 .

The fatty acid analysis of milk fat for period 1 is shown in Table 6. All major fatty acids were not different between the 2 groups of cows in period 1. The effects of $\mathrm{K}$ carbonate sesquihydrate supplementation on milk fatty acid concentration for period 2 is summarized in Table 7. Diet differences were noted for C16:1 (1.43 vs. 1.21 , control vs. $\mathrm{DCAD}+; P<0.05)$, the ratio of C16:1 to C16:0 (0.045 vs. 0.038, control vs. DCAD+;

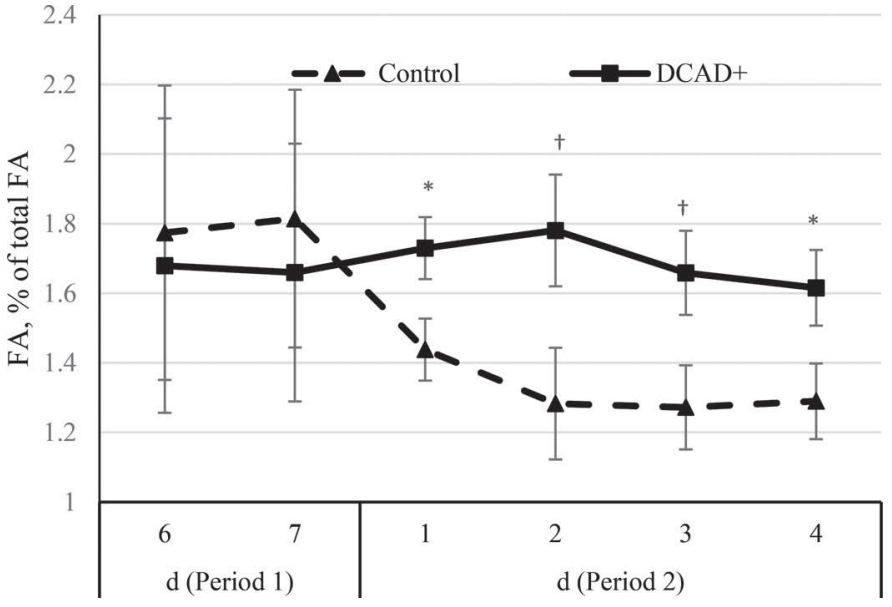

Figure 3. Concentration of C18:1, trans-11 fatty acid (FA) in milk (\% of total FA) as cows were fed the control diet in period 1 and control or $\mathrm{DCAD}+$ diets in period 2. $\dagger P<0.10,{ }^{*} P<0.05$. Day 6 and 7 are the last $2 \mathrm{~d}$ of period $1, \mathrm{~d} 1$ to 4 is first $4 \mathrm{~d}$ of period 2 and covariate adjusted, $1.7 \% \mathrm{~K}$ (control) or $2.3 \% \mathrm{~K}$ (DCAD+, Church and Dwight Co. Inc., Princeton, NJ). Period 1: treatment $P=0.77$, day $P$ $=0.70$, treatment $\times$ day $P=0.89$; period 2 : treatment $P=0.05$, day $P=0.26$, treatment $\times$ day $P=0.53$. Error bars represent $\mathrm{SE}$. 
Table 7. Fatty acid (\% of total fatty acids) profile of milk in period 2 of cows fed control or DCAD ${ }^{1}$

\begin{tabular}{|c|c|c|c|c|c|c|}
\hline Fatty acid & \multicolumn{2}{|c|}{ Treatment } & SEM & \multicolumn{3}{|c|}{$P$-value } \\
\hline C10:0 & 2.8 & 2.9 & 0.2 & 0.84 & 0.01 & 0.20 \\
\hline C14:0 & 12.8 & 13.2 & 0.40 & 0.47 & $<0.01$ & 0.41 \\
\hline C14:1 & 0.84 & 0.79 & 0.07 & 0.63 & $<0.01$ & 0.80 \\
\hline C14:1t & 0.14 & 0.16 & 0.02 & 0.51 & $<0.01$ & 0.42 \\
\hline C16:0 & 32.0 & 32.2 & 0.4 & 0.67 & 0.23 & 0.02 \\
\hline C16:1 & 1.43 & 1.21 & 0.06 & 0.04 & 0.61 & 0.72 \\
\hline Ratio C16:1/C16:0 & 0.045 & 0.038 & 0.002 & 0.07 & 0.37 & 0.38 \\
\hline C17:0 & 0.39 & 0.42 & 0.02 & 0.26 & 0.28 & 0.11 \\
\hline C18:0 & 10.1 & 10.4 & 0.4 & 0.54 & $<0.01$ & 0.07 \\
\hline C18:1 trans -8 & 0.24 & 0.25 & 0.04 & 0.93 & 0.06 & 0.69 \\
\hline C18:1 trans -9 & 0.25 & 0.22 & 0.04 & 0.59 & 0.47 & 0.07 \\
\hline $\mathrm{C} 18: 2$ & 3.8 & 3.6 & 0.1 & 0.84 & $<0.01$ & 0.49 \\
\hline C18:2 cis-9,trans- 11 & 0.67 & 0.82 & 0.07 & 0.16 & 0.24 & 0.28 \\
\hline C18:2 trans -10, cis- 12 & 0.03 & 0.03 & 0.01 & 0.83 & 0.52 & 0.14 \\
\hline $\mathrm{C} 18: 3$ & 0.57 & 0.6 & 0.02 & 0.42 & 0.01 & 0.28 \\
\hline $\mathrm{C} 20: 1$ trans-11 & 0.67 & 0.78 & 0.07 & 0.29 & 0.54 & 0.82 \\
\hline $\mathrm{C} 22: 1$ & 0.12 & 0.11 & 0.02 & 0.80 & $<0.01$ & 0.8 \\
\hline C24:0 & 1.7 & 1.5 & 0.2 & 0.48 & $<0.01$ & $<0.01$ \\
\hline De novo & 20.9 & 21.5 & 0.8 & 0.63 & $<0.01$ & 0.18 \\
\hline Mixed & 33.5 & 33.4 & 0.3 & 0.98 & 0.25 & 0.06 \\
\hline Preformed & 41.1 & 40.5 & 0.8 & 0.57 & $<0.01$ & 0.96 \\
\hline
\end{tabular}

${ }^{1}$ Data were covariate adjusted with data from period 1. DCAD+ (Church and Dwight Co. Inc., Princeton, NJ) diet only fed during period 2.

$P=0.07)$, and C18:1 trans-11 (1.3 vs. 1.6 , control vs. DCAD $+; P=0.05)$. The fatty acid composition in milk was in the range reported by Moate et al. (2007). Potassium carbonate sesquihydrate supplementation resulted in greater MUFA C18:1 trans-11 by $23 \%(P=$ $0.05)$, and less $\mathrm{C} 16: 1$ by $15.4 \%(P=0.04)$. The greater content of C18:1 trans-11 supports the hypothesis that feeding of $\mathrm{K}$ carbonate sesquihydrate promotes the normal (trans-11) biohydrogenation pathway (Grinari and Bauman, 1999; Harfoot and Hazlewood, 1997; Rico and Harvatine, 2013) instead of the altered pathway (trans-10). The total C18:2 concentration was not influenced by $\mathrm{K}$ carbonate sesquihydrate supplementation. The change of C18:1 trans-11 with time is shown in Figure 3. It was evident that within $24 \mathrm{~h} \mathrm{(d} \mathrm{1)} \mathrm{of} \mathrm{K} \mathrm{car-}$ bonate sesquihydrate supplementation, C18:1 trans-11 was greater $(P=0.05)$. The $\mathrm{C} 18: 1$ trans -10 and $\mathrm{C} 18: 2$ trans-10,cis-12 were not different between diets, and the lack of difference may be related to both groups of cows having a relatively high fat test.

Overall, supplementation of a diet with $\mathrm{K}$ carbonate sesquihydrate resulted in a greater milk fat concentration within $72 \mathrm{~h}$ of supplementation, and milk fat concentration remained greater when $\mathrm{K}$ carbonate ses- quihydrate supplementation was ceased. The difference in milk fat concentration was associated with a greater concentration of C18:1 trans-11 during the same time period, suggesting that the $\mathrm{K}$ carbonate sesquihydrate effect on milk fat concentration was mediated via a shift in biohydrogenation of C18:2 in the rumen.

\section{ACKNOWLEDGMENTS}

Funding for this project was provided by Arm \& Hammer Animal Nutrition (Princeton, NJ).

\section{REFERENCES}

Bauman, D. E., and J. M. Griinari. 2001. Regulation and nutritional manipulation of milk fat: Low-fat milk syndrome. Livest. Prod. Sci. 70:15-29.

Baumgard, L. H., J. K. Sangster, and D. E. Bauman. 2001. Milk fat synthesis in dairy cows is progressively reduced by increasing supplemental amounts of trans-10,cis-12 conjugated linoleic acid (CLA). J. Nutr. 131:1764-1769.

Grinari, J. M., and D. E. Bauman. 1999. Biosynthesis of conjugated linoleic acid and its incorporation into meat and milk in ruminants. Pages 180-200 in Advances Conjugated Linoleic Acid Res. Vol. 1. CRC Press, Boca Raton, FL. 
Harfoot, C. G., and G. P. Hazlewood. 1997. Lipid metabolism in the rumen. Pages 382-426 in The Rumen Microbial Ecosystem. Springer, Berlin, Germany.

Harrison, J., R. White, R. Kincaid, E. Block, T. Jenkins, and N. StPierre. 2012. Effectiveness of potassium carbonate sesquihydrate to increase dietary cation-anion difference in early lactation cows. J. Dairy Sci. 95:3919-3925.

Iwaniuk, M. E., and R. A. Erdman. 2015. Intake, milk production, ruminal, and feed efficiency responses to dietary cation-anion difference by lactating dairy cows. J. Dairy Sci. 98:8973-8985. http:// dx.doi.org/10.3168/jds.2015-9949.

Jenkins, T. C. 2010. Technical note: Common analytical errors yielding inaccurate results during analysis of fatty acids in feed and digesta samples. J. Dairy Sci. 93:1170-1174.
Jenkins, T. C., W. C. Bridges, J. H. Harrison, and K. M. Young. 2014. Addition of potassium carbonate to continuous cultures of mixed ruminal bacteria shifts volatile fatty acids and daily production of biohydrogenation intermediates. J. Dairy Sci. 97:975-984.

Moate, P. J., W. Chalupa, R. C. Boston, and I. J. Lean. 2007. Milk fatty acids. I. Variation in the concentration of individual fatty acids in bovine milk. J. Dairy Sci. 90:4730-4739.

Rico, D. E., and K. Harvatine. 2013. Induction of and recovery from milk fat depression occurs progressively in dairy cows switched between diets that differ in fiber and oil concentration. J. Dairy Sci. 96:6621-6630.

Sanchez, W. K., D. K. Beede, and J. A. Cornell. 1994. Interactions of sodium, potassium, and chloride on lactation, acid-base status, and mineral concentrations. J. Dairy Sci. 77:1661-1675. 